\title{
Effect of planting density on nutritional quality of green-chopped corn for silage ${ }^{1}$
}

\author{
Gonzalo Ferreira, ${ }^{* 2,3}$ Mauro Alfonso, $†$ Sebastián Depino, $†$ and Esteban Alessandri† \\ ${ }^{*}$ CREA Lincoln, Asociación Argentina de Consorcios Regionales de Experimentación Agrícola, Sarmiento 1236, \\ (1041) Ciudad Autónoma de Buenos Aires, Argentina \\ †Forratec Argentina SA, Acceso Elguea Román 1158 (6740), Chacabuco, Buenos Aires, Argentina
}

\section{ABSTRACT}

The objective of this on-farm study was to determine the effect of corn planting density on the nutritional quality of whole-plant corn for silage. This study was performed in a commercial 1,900-cow dairy farm located in Piedritas (Buenos Aires, Argentina). Two commercial hybrids (A and B) were planted in experimental plots within a cornfield destined for corn silage. Hybrids were sown at a theoretical seeding rate of $60,000,70,000$, 80,000 , and 90,000 seeds/ha in 4 replicates per hybrid. Plots were eight $50-\mathrm{m}-$ long rows separated by $52 \mathrm{~cm}$. Corn was planted with a no-till seeder equipped with a pneumatic dosing machine. Ten plants within each plot were cut by hand at $15 \mathrm{~cm}$ above ground. Whole plants were chopped, weighed, mixed thoroughly, and frozen until analysis. Nutritional composition was determined by near-infrared reflectance spectroscopy. Harvesting occurred at one-quarter milk-line $[31.4 \%$ dry matter (DM)] and one-half milk-line (34.5\% DM) stages of maturity for hybrids B and A, respectively. No interactions between hybrid and planting density were observed for any of the variables of interest. Planting density did not affect either plant DM weight or DM, crude protein, neutral detergent fiber, acid detergent fiber, or starch concentrations of whole-plant corn. Dry matter yield was significantly increased at higher planting densities. The similar per-plant biomass and nutritional quality among different densities can be explained by the abundant precipitation observed during this growing season (719 $\mathrm{mm}$ since the beginning of fallow until harvest). In conclusion, greater yields of silage can be obtained by increasing corn planting density without affecting its nutritional composition, although the effect of planting density with limiting resources (e.g., precipitation) still needs to be elucidated.

\footnotetext{
Received February 28, 2014.

Accepted May 24, 2014.

${ }^{1}$ The use of trade names in this study is for experimental purposes. No endorsements are herein implied.

${ }^{2}$ Current address: Department of Dairy Science, Virginia Tech, 175 W Campus Dr., Blacksburg 24061.

${ }^{3}$ Corresponding author: gonf@vt.edu
}

Key words: planting density, corn silage, nutritional quality

\section{INTRODUCTION}

Corn silage is a major energy and fiber source in diets for dairy cattle. Typical corn silage management decisions that affect forage quality, such as stage of maturity (Bal et al., 1997; Ferreira and Mertens, 2006), kernel processing (Schwab et al., 2002; Ferreira and Mertens, 2006), or cutting height (Wu and Roth, 2003; Kung et al., 2008) are focused on established corn crops. Although valid and transcendental, these decisions should not overlook that crop management decisions may also influence corn silage yield and quality.

Crop management practices for corn destined for grain are well established. Contrary to this, crop management practices for corn destined for silage are more controversial among farmers and consultants. For instance, in the western region of the temperate plains of Argentina, corn grain producers plant corn at relatively low densities (i.e., less than 75,000 seeds/ha), whereas dairy producers frequently plant corn at relatively high densities (i.e., more than 95,000 seeds/ha). A similar controversy is also observed from data within the United States. For instance, whereas Cusicanqui and Lauer (1999) observed maximum whole-plant DM yields when corn was planted at 97,300 to 102,200 plants/ha, corn hybrid trials for silage in the United States typically evaluated corn plots containing less than 90,000 plants/ ha (Lauer et al., 2012; Shaffer et al., 2013).

Considering total biomass yield as the only priority, planting corn for silage at high densities may be an attractive approach for dairy farmers to recover forage inventories. However, some major concerns exist with this practice. First, high corn planting densities may exacerbate the negative effects of droughty conditions, thereby resulting in reduced forage yields when they are most necessary. Second, planting corn at high densities may decrease the energy concentration of the resulting silage due to reduced kernel pollination or development (Subedi et al., 2006; Boomsma et al., 2009). Data from Boomsma et al. (2009) show that the grain-to-stover 
ratio diminishes when planting density is increased and the corn crop is not fertilized. Also, Subedi et al. (2006) reported a greater number of barren plants when the corn planting density was increased. Finally, Boomsma et al. (2009) reported that planting corn at high densities increases the anthesis-silking intervals, which may also result in lower grain-to-stover ratios. In agreement with these observations, Cusicanqui and Lauer (1999) reported that increasing corn planting density results in whole-plant corn silages with greater concentrations of fiber and, likely, less energy-containing corn silages. The negative relationship between planting density and forage quality makes difficult to recommend high planting density based on biomass yield (Cusicanqui and Lauer, 1999).

Field information regarding the effect of planting density on corn whole-plant yield and quality should add knowledge to better decide on crop management practices to obtain high yields of good-quality forage. The objective of this on-farm study was to determine the effect of corn planting density on the nutritional quality of whole-plant corn for silage.

\section{MATERIALS AND METHODS}

\section{Location, Hybrids, and Cultural Management}

This study was performed in a commercial 1,900cow dairy farm located in Piedritas $\left(34^{\circ} 43^{\prime} 56^{\prime \prime} \mathrm{S}\right.$ and $\left.62^{\circ} 57^{\prime} 59^{\prime \prime} \mathrm{W}\right)$, Buenos Aires, Argentina. Two commercial hybrids, DK747MGRR2 (hybrid A; DeKalb; Monsanto Co., Buenos Aires, Argentina) and DUO548HXRR2 (hybrid B; Forratec Argentina SA, Buenos Aires, Argentina), were planted in experimental plots within a cornfield destined for corn silage. Hybrid A was the corn material used by the dairy farm during that cropping season to recover corn silage inventories. Hybrid $\mathrm{B}$ is a commercial material, typically used for silage, and was included to broaden our conclusions to more than a single hybrid. Plots were planted and managed according to on-farm standard operating procedures. The cornfield was on a no-till soil management system. The preceding crop was corn for grain. The planting date was October 13, 2012.

Hybrids were planted at a theoretical seeding rate of $60,000,70,000,80,000$, and 90,000 seeds/ha in 4 replicates per hybrid according to a complete randomized block design with 4 blocks (i.e., 32 plots in total). Each of the 4 planting densities was randomly assigned to plots within each block. Plots consisted of eight 50-mlong rows separated by $52 \mathrm{~cm}$. Corn was planted with a 16-row no-till seeder equipped with a pneumatic dosing machine (Agrometal TX Mega; Agrometal SA, Córdoba, Argentina). Corn crops were fertilized with $90 \mathrm{~kg}$ of $\mathrm{N} /$ ha and $31 \mathrm{~kg}$ of $\mathrm{P}_{2} \mathrm{O}_{5} /$ ha. Weeds and insects were controlled following standard operating procedures for the cornfield. The total precipitation for the whole season (including fallow) was $719 \mathrm{~mm}$.

\section{Harvesting and Quality Determination}

Harvesting was targeted to occur when the whole plant contained between 30 and $35 \%$ DM, which occurred on February 5, 2013. At harvesting time, 5 consecutive plants from the center rows and at 2 randomly selected spots within each plot (i.e., 10 plants per plot) were cut by hand at $15 \mathrm{~cm}$ above ground. Whole plants were chopped with an experimental forage chopper (TRF 70; Trapp, Jaraguá do Sul, Brazil) and weighed to determine plant biomass. After mixing thoroughly by hand over a $2-\mathrm{m}$ by $2-\mathrm{m}$ plastic sheath, a sample of the chopped material was placed in a bag and immediately placed in a cooler with ice until frozen.

Single plant biomass and standing plants at harvest were used to determine biomass yield. For this, we counted the number of plants within a $9.6-\mathrm{m}$ row and in 2 adjacent rows. This procedure was performed for each of the 32 plots.

Whole-plant corn samples were then dried at $60^{\circ} \mathrm{C}$ in a forced-air drying oven until constant moisture was reached. Samples were then weighed to determine DM concentration of the field-moist samples. After drying, samples were ground to pass a 4-mm screen of a Wiley mill (Thomas Scientific, Swedesboro, NJ) and submitted to a laboratory. Within the laboratory, samples were reground to pass a 1-mm screen of a cyclone mill (LM 3100; Perten Instruments AB, Hägersten, Stockholm, Sweden) and finally analyzed with near-infrared reflectance spectroscopy (NIRS; Matrix I; Bruker Optics Inc., Billerica, MA). Coefficient of determination values for NIRS calibrations were 96.9, 93.3, 88.9, and 96.1 for $\mathrm{CP}, \mathrm{NDF}, \mathrm{ADF}$, and starch, respectively.

\section{Statistical Analysis}

Data were analyzed using PROC MIXED of SAS 9.3 (SAS Institute Inc., Cary, NC) as for a randomized complete block design with a $2 \times 4$ factorial arrangement of treatments (i.e., hybrids and planting densities). The model included the random effect of block (df $=3)$, the fixed effect of density $(\mathrm{df}=3)$, the fixed effect of hybrid $(\mathrm{df}=1)$, the density by hybrid interaction $(\mathrm{df}=3)$, and the residual error $(\mathrm{df}=21)$. The linear, quadratic, and cubic effects of planting density were also evaluated by orthogonal contrasts.

\section{RESULTS}

Harvesting occurred at one-quarter milk-line (31.4\% $\mathrm{DM})$ and one-half milk-line (34.5\% DM) stages of ma- 
turity for hybrids B and A, respectively. No interactions between hybrid and planting density were observed for any of the variables of interest $(P>0.22$; Table 1$)$. Plants from hybrid B were heavier than plants from hybrid A $(P<0.01)$, and DM yield tended to be higher for hybrid B than for hybrid A $(P<0.07)$. Crude protein $(P<0.01)$, NDF $(P<0.01)$, and ADF concentrations $(P<0.01)$ were higher and starch concentration was lower $(P<0.01)$ for hybrid B than for hybrid A.

Planting density did not affect plant DM weight $(P$ $<0.57)$, DM concentration $(P<0.50)$, CP concentration $(P<0.73)$, NDF concentration $(P<0.67)$, ADF concentration $(P<0.59)$, or starch concentration $(P<$ $0.24)$ of whole-plant corn. Dry matter yield was significantly greater at higher planting densities $(P<0.01)$.

\section{DISCUSSION}

Contrary to our expectations, planting density did not affect plant DM biomass or its nutritional quality (Table 1) and, therefore, increasing planting density resulted in greater DM yields per unit of land. Contrary to our results, Cusicanqui and Lauer (1999) reported that NDF concentration of whole-plant corn increased 4.1 to $6.0 \%$ units when planting density increased by 10,000 plants, suggesting that lower grain-to-stover ratios are observed at higher planting densities.

Supraoptimal corn planting density leads to intraspecific competition that is often associated with declines in above-ground per-plant total biomass, increased barrenness, and decreased harvesting indexes (Boomsma et al., 2009). In our study, the similar per-plant biomass and nutritional quality among different densities can be explained by the abundant precipitation observed during this growing season. Whereas the annual cumulative precipitation for the region from 1974 to 2011 averaged $887 \mathrm{~mm}$ (Instituto Nacional de Tecnología Agropecuaria, 2011), it rained $719 \mathrm{~mm}$ from the beginning of fallow to harvest. Abundant precipitation likely increases soil OM mineralization and nutrient uptake by corn plants (Djaman et al., 2013), thereby increasing soil nitrogen availability. Boomsma et al. (2009) reported similar harvesting indexes at a wide range of corn planting densities (i.e., from 54,000 to 104,000 plants/ha) when corn plots were side-dressed with nitrogen.

The observations from this study have major practical relevance when we consider the whole-forage management systems within dairy farms. Even though the effect of planting density on the nutritional quality of corn silage would still need to be evaluated under lessabundant precipitation regimens, the observations from this study suggest that under nonlimiting conditions (e.g., irrigated or highly fertile soils), corn planting density can be increased without being concerned of affect-

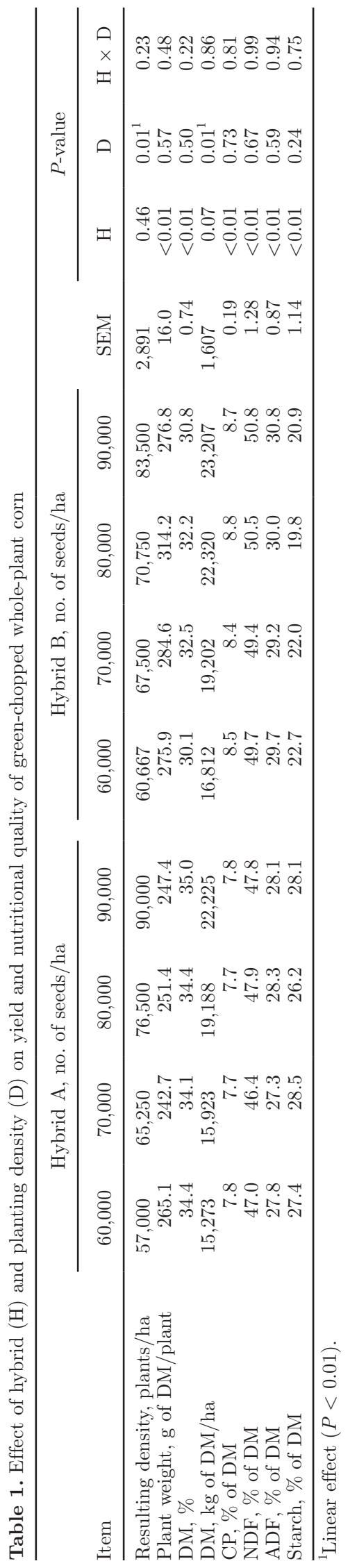


ing yield or nutritional quality of the corn silage. Given that corn for grain was the preceding crop in this study, the plots were prepared within a field with an extended fallow that would likely have allowed water accumulation and nutrient mineralization. Different from this situation, many dairy farmers double-crop their fields, planting winter crops for silage (e.g., ryegrass, oats, or barley) previous to the corn for silage. Under doublecropping conditions, water accumulation and nutrient mineralization can be substantially reduced, thereby limiting resources for the following corn crop destined for silage. Future research should evaluate whether increasing planting density affects corn silage yield and quality, depending on the preceding crop.

\section{CONCLUSIONS}

Corn plant density did not affect the quality of whole-plant corn destined for silage when precipitation was abundant. Therefore, greater yields of silage can be obtained by increasing corn plant density. Whether this observation is valid or not with limiting resources, such as precipitation or soil fertility, still needs to be elucidated. Information from this trial suggest that crop rotation and management should be considered when planning forage management strategies to obtain great quantities of good quality forage for dairy farming systems.

\section{ACKNOWLEDGMENTS}

We acknowledge Guillermo Bush and Guillermo Alfonso (Estancia El Pegual, Buenos Aires, Argentina) for collaborating on this project. We are greatly thankful to Daniel Carp, crop manager of Estancia El Pegual, and his field crew for their assistance during setting and planting of the corn plots. Open access for this article was supported by Virginia Tech's Open Access Subvention Fund.

\section{REFERENCES}

Bal, M. A., J. G. Coors, and R. D. Shaver. 1997. Impact of the maturity of corn for use as silage in the diets of dairy cows on intake, digestion, and milk production. J. Dairy Sci. 80:2497-2503.

Boomsma, C. R., J. B. Santini, M. Tollenaar, and T. J. Vyn. 2009 Maize morphophysiological responses to intense crowding and low nitrogen availability: An analysis and review. Agron. J. 101:14261452 .

Cusicanqui, J. A., and J. G. Lauer. 1999. Plant density and hybrid influence on corn forage yield and quality. Agron. J. 91:911-915.

Djaman, K., S. Irmak, D. L. Martin, R. B. Ferguson, and M. L. Bernards. 2013. Plant nutrient uptake and soil nutrient dynamics under full and limited irrigation and rainfed maize production. Agron. J. 105:527-538.

Ferreira, G., and D. R. Mertens. 2006. Effect of corn silage maturity and mechanical processing on nutrient digestibility by lactating dairy cows of different lactation stages. J. Dairy Sci. 89(Suppl. 1):192. (Abstr.)

Instituto Nacional de Tecnología Agropecuaria. 2011. Precipitaciones mensuales, Estación Experimental Agropecuaria General Villegas. Accessed Feb. 15, 2014. http://anterior.inta.gov.ar/f/?url=http:// anterior.inta.gov.ar/villegas/info/meteorologia.htm.

Kung, L., B. M. Boulder, C. M. Mulrooney, R. S. Teller, and R. J. Schmidt. 2008. The effect of silage cutting height on the nutritive value of a normal corn silage hybrid compared with brown midrib corn silage fed to lactating cows. J. Dairy Sci. 91:1451-1457.

Lauer, J., K. Kohn, and T. Diallo. 2012 Wisconsin corn hybrid performance trials - 2012. Publication A3653. University of WisconsinExtension, Madison.

Schwab, E. C., R. D. Shaver, K. J. Shinners, J. G. Lauer, and J. G. Coors. 2002. Processing and chop length effects in brown-midrib corn silage on intake, digestion, and milk production by dairy cows. J. Dairy Sci. 85:613-623.

Shaffer, J. A., G. W. Roth, J. A. Breining, and W. S. Harkcom. 2013. Pennsylvania commercial grain and silage hybrid corn tests report-2013 results. Accessed Feb. 27, 2014. http://pubs.cas.psu. edu/FreePubs/pdfs/uc194.pdf.

Subedi, K. D., B. L. Ma, and D. L. Smith. 2006. Response of a leafy and non-leafy maize hybrid to population densities and fertilizer nitrogen levels. Crop Sci. 46:1860-1869.

Wu, Z., and G. Roth. 2003. Considerations in managing cutting height of corn silage. Penn State Cooperative Extension Bulletin DAS 0372. Department of Dairy and Animal Science, The Pennsylvania State University, University Park. 